\title{
Recent Advances in Biological Activity, New Formulations and Prodrugs of Ferulic Acid
}

\author{
Monika Stompor-Gorący ${ }^{1, *([)}$ and Maciej Machaczka ${ }^{1,2} \mathbb{C}$ \\ 1 Department of Human Pathophysiology, Institute of Medical Sciences, University of Rzeszow, Kopisto 2a, \\ 35-959 Rzeszów, Poland; maciej.machaczka@ki.se \\ 2 Department of Clinical Science and Education, Division of Internal Medicine, Södersjukhuset, \\ Karolinska Institutet, 11883 Stockholm, Sweden \\ * Correspondence: monika.stompor@gmail.com
}

check for updates

Citation: Stompor-Goracy, M.;

Machaczka, M. Recent Advances in Biological Activity, New Formulations and Prodrugs of Ferulic Acid. Int. J. Mol. Sci. 2021, 22, 12889. https:// doi.org/10.3390/ijms222312889

Academic Editor: Manickam Sugumaran

Received: 8 October 2021

Accepted: 26 November 2021

Published: 28 November 2021

Publisher's Note: MDPI stays neutral with regard to jurisdictional claims in published maps and institutional affiliations.

Copyright: (c) 2021 by the authors. Licensee MDPI, Basel, Switzerland. This article is an open access article distributed under the terms and conditions of the Creative Commons Attribution (CC BY) license (https:/ / creativecommons.org/licenses/by/ $4.0 /)$.

\begin{abstract}
Trans-ferulic acid (FA) is a derivative of 4-hydroxycinnamic acid, which is found in many food products, fruits and beverages. It has scientifically proven antioxidant, anti-inflammatory and antibacterial properties. However, its low ability to permeate through biological barriers (e.g., the blood-brain barrier, BBB), its low bioavailability and its fast elimination from the gastrointestinal tract after oral administration limit its clinical use, e.g., for the treatment of neurodegenerative diseases, such as Alzheimer's disease. Therefore, new nanotechnological approaches are developed in order to regulate intracellular transport of ferulic acid. The objective of this review is to summarize the last decade's research on biological properties of ferulic acid and innovative ways of its delivery, supporting pharmacological therapy.
\end{abstract}

Keywords: ferulic acid; nanostructures; encapsulation; antioxidants; neuroprotective action

\section{Introduction}

Phenolic compounds are an important group of natural substances of plant origin. The health-promoting properties, such as anticancer, anti-inflammatory, etc., are possessed mainly by antioxidant compounds, and among them are flavonoids and phenolic acids [1-3]. For this reason, new methods of their functionalization are developed so as to increase their application in medicine [4,5].

Ferulic acid (FA) is found, among other, in the borage seeds, along with polyphenolic compounds, such as quercetin, galangin and naringenin. Seed extracts of various Borago species have high antiproliferative activity to HT-29 human colon cancer cells [6]. It is also an ingredient of wheat bran, where it is found in the form of esters with sugars, such as arabinose [7]. Meanwhile, in the form of glucosides, it is present, among others, in Nitraria sibirica [8]. Bioavailability of ferulic acid is dependent on thermal treatment of food products. It was observed that boiling of whole-grain barley varieties enhanced extractability of phenolic acids [9]. Free ferulic acid, including in the form of esters, is also found in the Persian walnut Juglans regia [10]. Additionally, it is the main ingredient of foxtail millet phenolic extracts, which are highly active $\alpha$-glucosidase inhibitors [11]. Moreover, it was identified in the marine brown seaweed Padina tetrastromatica, which may be used for development of functional food with antidiabetic and antioxidant activities [12] and in oleoresin from the Curcuma plant, which is a food industry waste [13]. In addition, ferulic acid is found in pectin from sugar beet (Beta vulgaris) pulp obtained by extraction with subcritical water [14] and in propolis [15].

From a medical point of view ferulic acid plays an important role in treatment of neurodegenerative diseases, diabetes, cardiovascular diseases, inflammation, and also bacterial and viral infections (Figure 1). It imposes an effect on structures and properties of digestive enzymes, such as pepsin; thus, it may be an important ingredient in formulations of food products for special medical purposes [16]. 


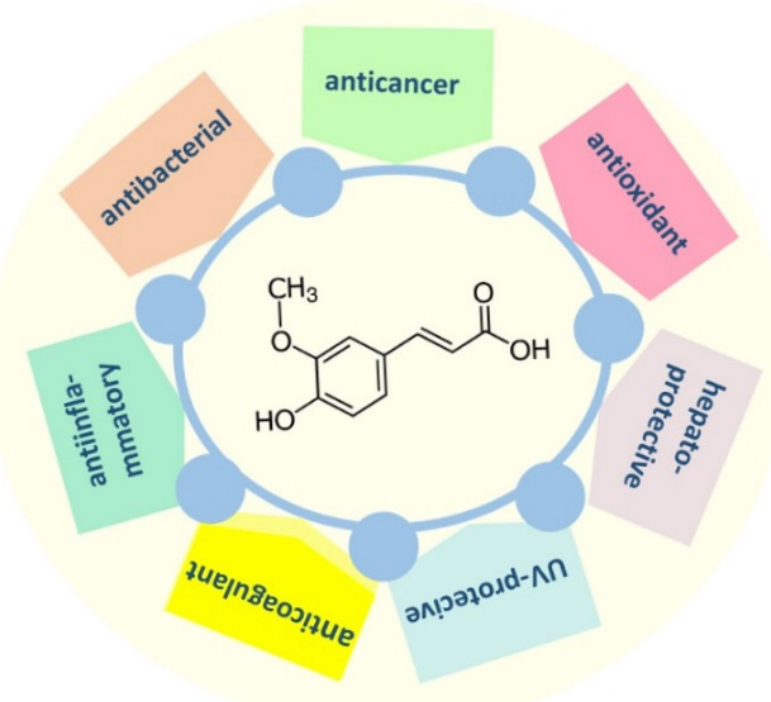

Figure 1. Biological activity of ferulic acid.

Ferulic acid and its structural analogues have high antioxidant activity [17]. Being an ingredient of green coffee, it inhibits the activity of monoamine oxidase (MAO) - the enzyme that is responsible for deamination of the central nervous system (CNS) neurotransmitters, such as serotonin (5-HT), for which decreased levels lead to depression and disorders of the satiety center [18]. According to earlier reports, increased levels of serotonin and norepinephrine in the hippocampus and frontal cortex were observed in mice treated with ferulic acid [19]. The compound shows antithrombotic activity [20] and anti-inflammatory properties and has a protective function in eye diseases, such as retinal degeneration (observed after supplementation of mice diet with $50 \mathrm{mg} / \mathrm{kg}$ of FA) [21]. It also alleviates acute lung injury through inhibiting the TLR4/NF- $\mathrm{KB}$ signaling pathway [22]. Ferulic acid amide derivatives demonstrated in vivo antidiabetic and hypolipidemic effects [23]. In addition, topical application of ferulic acid and its structural analogues may be an efficient and safe method of skin protection against photodamage. FA may be used as an antioxidant to prevent damage from ultraviolet (UV) radiation and skin carcinogenesis [24]. The chemical structure and, resulting from it, physicochemical properties, such as the intercalation into cell membranes, determine the biological activity of ferulic acid [25]. The compound is well soluble in fats and ethanol, whereas its solubility in water is low. Thus, so as to attain the optimal pharmacological activity, new formulations with ferulic acid must be well soluble in water and body fluids. Taking into account the interesting biological properties of ferulic acid and limitations in its medical use, the aim of this review is to sum up the most recent research on pharmacological activity of this compound and new ways of its delivery based on nanocarriers, so as to increase the physiological role of phenolic acids and their derivatives. We summarized the research concerning ferulic acid, its properties and innovative functionalization methods that have been reported over the last decade, in order to facilitate further study on using natural antioxidants, including phenolic acids, in pharmacology and clinical trials. The recent advances in synthesis of some FA prodrugs were also analyzed.

\section{Main Pharmacological Properties of FA}

\subsection{Detoxification and Hepatoprotective Effects}

Naturally occurring methoxylated phenolic acids, including FA, are thoroughly studied with respect to their detoxifying properties, because they may be used for treatment of drug-induced side effects and for preventing toxicity caused for example by polyun- 
saturated fatty acids, carbon tetrachloride, arsenic or cadmium tetrachloride. Ferulic acid inhibits liver fibrosis progression in non-alcoholic steatohepatitis (NASH) [26]. One of the mechanisms of the activity of FA and its derivatives is also their ability to decrease the levels of proinflammatory cytokines, indicating that FA is beneficial to the immune system [27].

Ferulic acid mitigates arsenic-induced developmental cardiotoxicity [28], ameliorates lead-induced cognitive deficits in vivo [29] and shows protective effect against cadmium chloride-mediated reproductive toxicity [30]. Additionally, it protects the male reproductive system from arsenic-induced toxicity [31] and protects liver cells from the tetrachlorideinduced injury [32].

Moreover, ferulic acid has protective effect against cardiac toxicity caused by doxorubicin in rats [33]. Bami et al. [34] demonstrated that treatment with ferulic acid prevents oxidative stress and regulates the levels of BUN (blood urea nitrogen), creatinine, MDA (malondialdehyde), MPO (myeloperoxidase), TOS (total antioxidant status) and PtNT (protein nitrotyrosine) in rats treated with cisplatin. The cardioprotective effect of FA against isoproterenol-induced cardiac toxicity in rats was described by Jain et al. [35].

The studies on the alleviation of arsenic-induced cardiotoxicity have also been documented [28].

The antioxidant activity of ferulic acid leads to the reduction of harmful effects caused by lead acetate, which is an ingredient of many cosmetics, hair dyes and plant protection chemicals [36]. Moreover, the oral administration of ferulic acid to rats fed with a high-fat diet alleviated development of non-alcoholic fatty liver disease (NAFLD) by reducing the deposition of triglycerides and cholesterol in the liver [37]. The compound protects AML-12 hepatocytes against palmitate-induced lipotoxicity by reducing ROS (reactive oxygen species) accumulation and decreasing activation of proinflammatory cytokines, i.e., IL-6 and IL-1 $\beta$ [38]. Therefore, the development of new forms of functional foods enriched with ferulic acid is reasonable in the case of metabolic diseases. The in vivo study with TAC (total antioxidant capacity assay) mice showed that FA exerts a positive effect on gut microbiota, and, in this way, it improves cardiac functions [39]. It also has a modulatory effect on dysregulated redox balance in ferric-induced pancreatic oxidative injury [40].

Ferulic acid can prevent acute liver injury by ameliorating inflammation and regulating GSK-3 $\beta / \mathrm{NF}-\mathrm{KB} / \mathrm{CREB}$ pathway. It also decreases the activity of MPO, aspartate aminotransferase (AST) and alanine aminotransferase (ALT) [41] and alleviates lipopolysaccharideinduced inflammation and acute lung injury in mice [22].

\subsection{Anticancer Activity}

The anticancer activity of natural ferulic acid arises mostly from its capability to suppress reactive oxygen species that protects cellular components, such as DNA, peptides and lipids, from oxidative damage. Moreover, the activity is due to the regulatory effect of FA on intracellular signaling pathways, proliferation, apoptosis and metastasis [42-45]. In the future, ferulic acid may be an important ingredient of multicomponent formulations, alleviating adverse effects of common chemotherapeutics used in treatment of drug-resistant cancers [46].

It is known that ferulic acid has antitumor activity and that, at high doses, it is less toxic to normal cells than to cancer ones. At a single dose of $300 \mu \mathrm{g} / \mathrm{mL}$ for $10 \mathrm{~min}$, it did not cause any toxicity to platelets $\left(10^{3} / \mathrm{mL}\right)$, leukocytes $\left(10^{3} / \mathrm{mL}\right)$ and erythrocytes $\left(10^{6} / \mathrm{mL}\right)$ from blood samples that were drawn from healthy rodents [20]. There is also evidence that high concentrations of FA ( 500 and $1000 \mu \mathrm{M})$ do not influence the cell viability in 786-O human renal cancer cells [47]. Nevertheless, FA has proven anticancer activity against the cells of human renal adenocarcinoma (ACHN) [48], human urinary bladder carcinoma (T24) [49], human breast cancer (MDA-MB-231) [45] and human osteosarcoma (143B and MG63) [50]. After a 48-h exposure of breast cancer cells (MCF-7) and liver cancer cells (HepG2) to ferulic acid, the measured half-maximal inhibitory concentration values ( $\mathrm{IC}_{50}$ ) were 75.4 and $81.38 \mu \mathrm{g} / \mathrm{mL}$, respectively. Additionally, the observed elevated levels of caspase- 8 and -9 indicated induction of apoptosis in the tested cancer cell lines [51]. More- 
over, FA at the concentration of $2 \mathrm{mM}$ inhibits proliferation of human cervical cancer cells HeLa and Caski by 88.3 and $85.5 \%$, respectively, inducing cell cycle arrest [52]. Moreover, ferulic acid at a dose of $200 \mu \mathrm{M}$ inhibits the adhesion and migration of human lung (A549) and colon adenocarcinoma (HT29-D4) cancer cells by 77.9 and $79.8 \%$, respectively [53]. Combination of ferulic acid $(10 \mu \mathrm{M})$ with drugs, such as epirubicin $(1 \mu \mathrm{M})$, is a promising therapeutic option for the treatment of breast cancer (MDA-MB-231) [54]. Moreover, the compound enhances the effects of radiotherapy in lung (A549) and liver (HepG2) cancers in later stages of treatment and protects normal lung fibroblasts (WI38) and peripheral blood mononuclear cells (PBMCs) from radiation damage [55]. Moreover, derivatives of FA, due to their strong histone deacetylase inhibitory activity, offer a promising strategy for cancer therapy [56].

\subsection{Other Properties of Ferulic Acid}

Among other significant activities of FA, it is worth noting that it has antimicrobial, photoprotective and anti-inflammatory properties [57,58]. For this reason, the compound is found as an ingredient of dermocosmetic formulations against aging, hyperpigmentation and acne [59]. There are also known neuroprotective [60]) and antidiabetic [61] properties of ferulic acid, including the synergistic interaction of FA with hypoglycemic drugs [62].

Ferulic acid has antimicrobial activity, e.g., towards pathogenic bacteria E. coli O157:H7 ATCC 43888 and L. monocytogenes ATCC 7644 [63]. For this reason, it finds application as an ingredient of antibacterial packaging materials based on natural polysaccharides. Composite bacterial cellulose-chitosan membranes grafted with ferulic acid may find applications in the food industry as a packaging material to extend the shelf life of food and as dressing materials for slow-healing wounds [64]. Moreover, Liu et al. [65] used ferulic acid for the preparation of innovative composite films used as a packaging material for the preservation of shrimps. Moreover, it was shown that ferulic acid may ameliorate sepsis-induced multi-organ failure. In the in vivo study in rats, the treatment with FA decreased the levels of malondialdehyde (which is an oxidative stress marker), while increasing both the levels of glutathione and the activity of superoxide dismutase and glutathione peroxidase, which protect the organism against the damages of oxidative stress in sepsis [66]. The increased level of oxidative stress may also have an impact on the activity of tyrosinase, the enzyme belonging to the oxidase family. Ferulic acid, in combination with 4-hydroxycinnamic acid, effectively inhibits tyrosinase activity (inhibition rate of 90.44\%) [67].

\section{Novel Strategies for Ferulic Acid Drug Delivery}

Phenolic antioxidants, such as ferulic acid, have low toxicity and many important physiological functions; therefore, they are widely used in pharmaceutical, food and cosmetic industries. They are free radical scavengers, have affinity for lipid substrates and may be important factors for antioxidant activity. However, their application is limited due to their hydrophobic character and fast decomposition after oral application. For this reason, new ways of its delivery, characterized by sustained release, are being developed (Figure 2). The most common base materials used for the production of novel nanoformulations with FA comprise dendrimers, polymers, certain enzymes, lipids, polysaccharides and also noble metal ions, such as gold.

Qi et al. [68] proposed a novel oxygen delivery system based on hemoglobin modified with ferulic acid that has the capacity to reduce oxidative side reactions and may be used for production of red-blood-cell substitutes.

There is also research on new methods for the functionalization of ferulic acid in order to improve its hydrophilicity. Yao and Sun [69] studied the possibility to use lipases: Candida antartica lipase-B, Candida antartica lipase-A and Thermomyces lanuginosus (Lipozyme TL 100L) for preparation of glyceryl ferulate, which is an easily absorbable form of ferulic acid that is used in cosmetology for the production of dermocosmetics that protect skin from UV irradiation. 


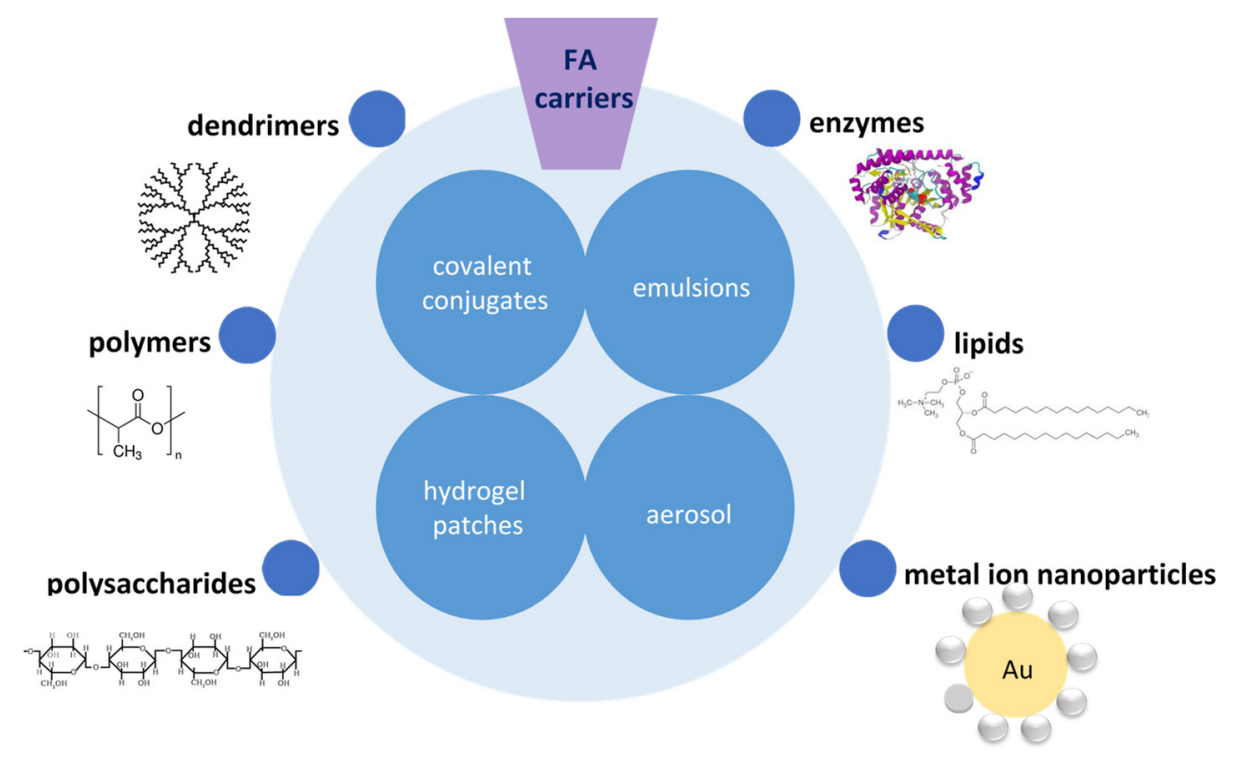

Figure 2. Novel formulations of ferulic acid (FA).

An interesting way of simultaneous delivery of antioxidants of different lipophilicity are solid-lipid nanoparticles. Oehlke et al. [70] used the method of hot homogenization to prepare solid-lipid nanoparticles loaded with ferulic acid and tocopherol. The formulations proved to have high antioxidant activity.

One of the innovative methods in modern aesthetic medicine is laser-assisted drug delivery (LAD), which is used to improve the penetration of drugs into the skin, for example, in treatment of scars [71]. A laser-assisted method of delivery of ferulic acid together with vitamins $C$ and $E$ was developed by Waibel et al. [72]. Transdermal delivery of ferulic acid by using microneedle arrays was studied by Yang et al. [73]. The group of Bai et al. [74] prepared transdermal hydrogel patches with ferulic acid on the basis of glycerin, dihydroxyaluminum aminoacetate and tartaric acid. Important for dermatology and cosmetology is the development of innovative triptolide gels with ferulic acid, with potential clinical importance [75]. Meanwhile, aerosol delivery of ferulic acid-loaded nanostructured lipid carriers is a promising approach for the treatment of the respiratory disorders [76].

Del Olmo et al. [77] performed the reaction of amidation-obtained first-generation carbosilane dendrimers functionalized with ferulic acid. These new polyphenolic compounds exhibited higher antioxidant properties than free ferulic acid. The analogous reaction with caffeic and gallic acids gave compounds that inhibited the growth of Gram-positive (+) and Gram-negative (-) bacteria.

Anbazhagan et al. [78] prepared ferulic acid (FA) and paclitaxel (PTX) co-loaded polyamidoamine (PAMAM) dendrimers $\mathrm{G} 4.5$ conjugated with arginyl-glycyl-aspartic acid (RGD) to overcome P-glycoprotein (P-gp)-mediated multidrug resistance (MDR). Ferulic acid delivered in the form of the RGD-PAMAM nanoaggregate enhanced intracellular availability of the medication and induced apoptosis in P-gp-overexpressing multidrugresistant cells.

A more sophisticated method of increasing FA delivery in topical applications is the development of polymeric nanocarriers. The size of nanoparticles ranges from 10 to $1000 \mathrm{~nm}$, and, most often, they are based on poly(lactic-co-glycolic acid) PLGA. The FA-encapsulated PLGA/PEO nanofibers showed high proapoptotic activity against human breast carcinoma cells (MCF-7) [79].

Rajendran et al. [80] synthesized gold nanoparticles containing ferulic acid as a stabilizing agent (FA-AuNPs), which was next tested for cytotoxicity on human skin cancer cells (A431) and normal keratinocytes (HaCaT). The results confirmed that FA-AuNPs can be used in dermato-oncology in the future, because they induce apoptosis in A431 cells. 
Johnson et al. [81] incorporated an FA molecule into fructo-oligosaccharide in order to develop an oral prodrug active against colorectal cancer cells. Additionally, biocompatible hydrogels based on poly-( $N$-isopropylacrylamide) (PNIPAM) and copolymers crosslinked with $\mathrm{N}, \mathrm{N}$-methylenebisacrylamide (BIS) were proposed as scaffold materials for antioxidants [82].

A new way to improve the deficiency of phenolic acids is using a vesicular drug delivery system. Rezaeiroshan et al. [83] designed and prepared niosomes-the vesicles composed of non-ionic surfactants. Recent developments in therapeutic and nutraceutical applications of $\mathrm{p}$-methoxycinnamic acid from plant origin formulations with ferulic acid. Then, the new preparation was evaluated for the in vivo anti-inflammatory activity in rats, using the carrageenan-induced rat paw oedema test. The tested biogel inhibited the oedema by over $20 \%$.

Hassanzadeh et al. [84] designed a nanoformulation based on the silk fibroin as a biomimetic substance coated with neutrophil-membrane-modified ferulic acid. The prepared nanoparticles improved the pharmacological profile of FA and afforded selective delivery of FA into the inflammatory pancreas lesion.

Thermosensitive chitosan/gelatin-based hydrogel containing encapsulated ferulic acid was designed by Wang et al. [85]. The new preparation provided the sustained release of FA. Moreover, it decreased endogenous reactive oxygen species production, improved flow of blood, improved muscle regeneration and decreased inflammation in veins. Therefore, it may be useful in therapy of peripheral arterial disease.

An excellent way to increase the delivery of FA after oral administration was the development of a new nanocarrier system based on chitosan nanoparticles loaded with phospholipid complex (FAPLC CNP) [86]. Another method to improve therapeutic efficacy of ferulic acid may be using aerosolized chitosan nanoparticles, which are supposed to be effective in treatment of asthma [87]. Chitosan-ferulic-bovine serum albumin microcapsules, obtained by the spray-drying technique, demonstrated high thermal stability and in vitro sustained release; thus, they may find application as carriers in novel functional foods, as well as in drug delivery systems [88]. Dermal absorption of ferulic acid delivered in the form of stable $\mathrm{w} / \mathrm{o} / \mathrm{w}$ emulsions with antioxidant properties was developed by the team of Mancuso et al. [89]. The formulation proved capable to treat UV-B-induced erythema.

Amphiphilic polymers of chitosan with $\epsilon$-caprolactone and covalently bonded ferulic acid were prepared for the targeted delivery of antitubercular drugs by Praphakar et al. [90]. Poornima and Korrapati [91] developed innovative nanofibers based on the polycaprolactone-grafted chitosan for the simultaneous delivery of ferulic acid and resveratrol.

Phenolic acids, due to their antioxidant properties, represent an attractive research topic in the field of innovative nutraceuticals. Stable lipid-core nanocapsules based on poly $(\varepsilon-$ caprolactone) polymer and loaded with ferulic acid were prepared by Granata et al. [92].

Panwar et al. [93] used an ionic gelation method to prepare chitosan-tripolyphosphate pentasodium (CS-TPP) nanoparticles (NPs) with ferulic acid. The obtained formulation exerted a high antiproliferative effect on human cervical carcinoma cells ME-180.

A promising solution seems to be using a free-radical-induced grafting procedure (ascorbic acid/hydrogen peroxide pair as radical initiator) to prepare chitosan-ferulic acid nanocapsules with application potential [94]. Moreover, ferulic acid in combination with aspirin shows chemopreventive potential towards pancreatic cancer when delivered using chitosan-coated solid-lipid nanoparticles [95].

There is also known a method of preparation of new pharmaceuticals with the use of cellulose acetate as a polymeric matrix for ferulic acid. One of the methods is to prepare a cellulose acetate membrane impregnated with a lipid solution, aiming to mimic skinbarrier function for ferulic acid release [96].

The obtained formulation ensures the sustained release of the active substance [97]. Attempts have also been made to immobilize FA in the solid porous resin Lewatit ${ }^{\circledR}$, which provides the nanoparticles with narrow size distributions [98]. 
The antioxidant activity of ferulic acid was an inspiration for designing an innovative ophthalmic insert composed of hyaluronan nanofibers and $\varepsilon$-polylysine for the treatment of eye diseases [99]. Similarly, Varela-Garcia et al. [100] designed innovative polymeric contact lenses for the controlled delivery of ocular drugs with ferulic acid. Hydrogels were prepared from the mixtures of 2-hydroxyethyl methacrylate (HEMA), glycidyl methacrylate (GMA) and ethyleneglycolphenylether methacrylate (EGPEM). The proposed solution may be used for the treatment of several eye diseases, including age-related ones. Furthermore, Romeo et al. [101] proposed ferulic acid delivery through polymeric nanoparticles (NPs) consisting of polylactic acid (PLA) and poly(lactic-co-glycolic acid) (NPB) as an effective system for the treatment of eye problems.

A new way of oral FA delivery aiming to reduce the rate of its metabolic conversion and renal elimination, along with increasing its distribution in the brain and improving hypnotic efficacy, was proposed by Liu et al. [102].

In the search for effective ways to control the delivery of antioxidants, whey protein, in combination with maltodextrin, is also studied. Zyaitdinov et al. [103] used this method to encapsulate the polyphenols from oat bran with a high content of ferulic acid. This technique may be used for the preparation of functional food, rich in nutraceuticals. Zeincasein-lysine protein nanoparticles were developed by Reference [104] to modulate the intestinal permeability of ferulic acid and to afford its sustained delivery.

Nanoparticles of ferulic acid and zinc oxide have cytoprotective activity against renal ischemia, which may be due to the enhancement of cell proliferation, upregulation of the antioxidant genes expression (e.g., Nrf2, HIF-1 $\alpha$ ) or their anti-inflammatory activity (downregulation of TNF- $\alpha$ ) [105].

Moreover, in recent years, the development of safe methods of delivery of chemotherapeutics to cancer cells, with the help of non-toxic carriers, has gained more and more importance. Polymers based on natural products may serve as such matrices. Nanoparticles of poly (ferulic acid)-containing doxorubicin (PFA-DOX) demonstrated reduced physical toxicity in vivo compared with free doxorubicin. Additionally, PFA nanocarriers promoted the accumulation of a chemotherapeutic at the tumor site, which supports tumor suppression [106].

Conjugates of ferulic acid with carboxylic curdlans had lower thermal stability and rheological properties than carboxylic curdlans without FA, but their antioxidant activity was very high. Emulsions containing these conjugates showed good $\beta$-carotene stability, whereas emulsions without FA did not protect $\beta$-carotene from chemical degradation [107].

The o/w emulsions stabilized with ferulic acid-grafted curdlan conjugate (Cur-Dg-FA) were also obtained by Yu et al. [108] in order to improve chemical stability and bioavailability of $\beta$-carotene.

Nanocomposite gels based on alginate and prebiotic arabinoxylan materials containing probiotic bacterial cultures (Lactobacillus plantarum) and ferulic acid $(1.78 \mu \mathrm{g} / \mathrm{g}$ of arabinoxylan oligosaccharides) demonstrated high stability and resistance to gastric conditions [109]. The new nanosystems for ferulic acid delivery are summarized in Table 1.

Table 1. The new formulations of ferulic acid.

\begin{tabular}{ccc}
\hline Formulation & Physicochemical Characteristic & Activity \\
\hline $\begin{array}{c}\text { FA-SLN } \\
\text { Solid-lipid nanoparticles loaded with } \\
\text { ferulic acid }\end{array}$ & $\begin{array}{c}\text { Zeta potential: }-25 \text { to }-43 \mathrm{mV} \\
\text { Final FA contents in the SLN: 0.56 and } \\
2.80 \mathrm{mg} \mathrm{g}^{-1} \text { of dispersion }\end{array}$ & Stable antioxidant activity \\
\hline $\begin{array}{c}\text { Laser-assisted method of delivery of } \\
\text { ferulic acid together with vitamins C }\end{array}$ & No data & $\begin{array}{c}\text { Wound healing and } \\
\text { prevents scarring }\end{array}$ \\
\hline $\begin{array}{c}\text { Transdermal hydrogel patches with } \\
\text { ferulic acid, on the basis of glycerin, } \\
\text { dihydroxyaluminum aminoacetate and } \\
\text { tartaric acid }\end{array}$ & No data & $\begin{array}{c}\uparrow \text { Release of FA from the paste; } \\
\text { [ifficult to permeate through the skin barrier }\end{array}$ \\
\hline
\end{tabular}


Table 1. Cont.

\begin{tabular}{|c|c|c|c|}
\hline Formulation & Physicochemical Characteristic & Activity & Reference \\
\hline $\begin{array}{c}\text { FA-loaded NLCs } \\
\text { Aerosol delivery of ferulic acid-loaded } \\
\text { nanostructured lipid carriers }\end{array}$ & $\begin{array}{c}\text { Particle size: } 54.9-148.6 \mathrm{~nm} \\
\text { Polydispersity index: } 0.15-0.37 \\
\text { Zeta potential: }(-19.8)-(-25.3) \mathrm{mV} \\
\text { Entrapment efficiency: } 44.3-94.3 \%\end{array}$ & $\begin{array}{c}\uparrow \text { Period of cytotoxicity time against lung } \\
\text { cancer cells (A549); } \\
\uparrow \text { Pharmacokinetic } \\
\text { profile of FA }\end{array}$ & [76] \\
\hline $\begin{array}{c}\mathrm{Gn}-[\mathrm{Si}(\mathrm{CH} 2) 3 \mathrm{NHC}(\mathrm{O}) \mathrm{FA}]_{2}(\mathrm{G} 1) \\
\mathrm{Gn}-[\mathrm{Si}(\mathrm{CH} 2) 3 \mathrm{NHC}(\mathrm{O}) \mathrm{FA}]_{8}(\mathrm{G} 2) \\
\text { First-generation carbosilane dendrimers } \\
\text { functionalized with ferulic acid }\end{array}$ & NMR characterized & $\begin{array}{l}\text { No improving the antioxidant activity (DPPH) } \\
\text { Antibacterial activity: } \\
\begin{array}{r}\text { MIC (ppm) > } 16 \text { (S. aureus and E. coli) } \\
\% \text { Viability of HFF cells: } \\
95.4 \text { (G1) } \\
92.9(\mathrm{G} 2)\end{array}\end{array}$ & [77] \\
\hline $\begin{array}{c}\text { RGD-PAMAM-FP } \\
\text { Ferulic acid (FA) and paclitaxel (PTX) } \\
\text { co-loaded polyamidoamine (PAMAM) } \\
\text { dendrimers G 4.5 conjugated with } \\
\text { arginyl-glycyl-aspartic acid (RGD) }\end{array}$ & $\begin{array}{l}\text { Zeta potential: }-31.3 \mathrm{mV} \\
\text { Size: } 144.6 \mathrm{~nm}\end{array}$ & $\begin{array}{c}\uparrow \text { Release of FA; } \\
\uparrow \text { effectiveness of } \\
\text { drug therapy, especially in the treatment of } \\
\text { MDR cancers; } \\
\downarrow \text { P-glycoprotein } \\
\text { expression }\end{array}$ & [78] \\
\hline FA-encapsulated PLGA/PEO nanofibers & $\begin{array}{l}\text { Fiber diameter: } 150 \pm 47.4 \text { to } \\
\qquad 200 \pm 79 \mathrm{~nm}\end{array}$ & $\begin{array}{c}\text { Morphological changes in MCF- } 7 \text { cells signs } \\
\text { for antiapoptotic effect; } \\
\downarrow \text { viability of HEK- } 293 \text { cells }\end{array}$ & [79] \\
\hline FA-AuNPs & $\begin{array}{c}\text { Size: } 34.2 \mathrm{~nm} \\
\text { Polydispersity index }(\mathrm{PDI})=0.137\end{array}$ & $\begin{array}{c}\text { Antiangiogenic properties; encouraged } \\
\text { programmed cell death in A431 cells. } \\
\text { Proapoptotic: } \\
\downarrow \text { Mitochondrial membrane potential, } \\
\text { Improved the ROS; } \uparrow \text { activation of caspase-3 } \\
\text { leading to apoptosis }\end{array}$ & [80] \\
\hline $\begin{array}{l}\text { Biocompatible hydrogels based on } \\
\text { poly-( } N \text {-isopropylacrylamide) } \\
\text { (PNIPAM) and copolymers crosslinked } \\
\text { with } N, N \text {-methylenebisacrylamide (BIS) }\end{array}$ & No data & $\begin{array}{c}\uparrow \text { Antioxidant properties; } \\
\uparrow \text { time release }\end{array}$ & [82] \\
\hline $\begin{array}{l}\text { Niosomal biogel of TFA } \\
\text { (trans-ferulic acid) }\end{array}$ & $\begin{array}{c}\mathrm{EE}=21.64 \% \\
\text { Particle size: } 158.7 \mathrm{~nm}\end{array}$ & $\begin{array}{c}\text { Anti-inflammatory effect; } \\
\text { inhibited the oedema about } 21.37 \%\end{array}$ & [83] \\
\hline $\begin{array}{l}\text { FA-SF-NPs } \\
\text { nanoformulation based on the } \\
\text { silk fibroin }\end{array}$ & $\begin{array}{c}\text { Size: } 186.3 \mathrm{~nm} \\
\text { PDI: } 0.17 \\
\text { Zeta potential: }-36.4 \mathrm{mV}\end{array}$ & $\begin{array}{c}\downarrow \text { Levels of enzymes; } \\
\text { prevented the significant enhancement of the } \\
\text { inflammatory cytokine levels IL- } 1 \beta, \text { TNF- } \alpha \\
\text { and IL-6; and } \\
\text { selective accumulation of FA in the } \\
\text { inflammatory lesions of the pancreas }\end{array}$ & [84] \\
\hline $\begin{array}{c}\text { FA-gel } \\
\text { chitosan/gelatin-based hydrogel } \\
\text { containing encapsulated ferulic acid }\end{array}$ & $\begin{array}{c}\text { Gelation time: } 64.75 \pm 3.31 \mathrm{~s} \text { at } \\
37^{\circ} \mathrm{C}\end{array}$ & $\begin{array}{c}\text { Antioxidant effect; } \\
\text { decreasing endogenous reactive oxygen } \\
\text { species production, inflammation-related gene } \\
\text { expression and apoptosis level; improves } \\
\text { blood flow and muscle regeneration; and } \\
\text { decreases inflammation in veins }\end{array}$ & [85] \\
\hline
\end{tabular}

Chitosan nanoparticles loaded with phospholipid complex (FA-FAPLC CNP)

\section{Particle size $\sim 123.27 \mathrm{~nm}$,}

PDI value $\sim 0.31$

Zeta potential: $\sim 32 \mathrm{mV}$ Spherical-shaped morphology $\uparrow$ Aqueous solubility of FA around $\sim(12$-fold $)$, $\uparrow$ antioxidant activity and $\uparrow$ oral bioavailability

Size: $164.2 \pm 9.7 \mathrm{~nm}$

Zeta potential: $(24.0 \pm 0.5 \mathrm{mV})$

Entrapment efficiency: (EE\%) $(65.0 \pm 1.5)$

Aerosolized hyaluronic acid decorated, ferulic acid-loaded chitosan nanoparticles

Loading capacity: (LC\%) $(18.5 \pm 0.4)$

$\uparrow$ Interaction and transportation across mucus barrier

Mass median aerodynamic diameter

(MMAD) of $1.81 \pm 0.15 \mu \mathrm{m}$

Ferulic acid delivered in the form of stable $\mathrm{w} / \mathrm{o} / \mathrm{w}$ emulsions

CS-g-PCL/FA

chitosan with $\epsilon$-caprolactone and covalently bonded FA
Average size: 100-210 nm $\uparrow$ Percutaneous permeation;
possible topical application in
photo-induced erythema

Potential for delivery of hydrophobic antitubercular drugs 
Table 1. Cont.

\begin{tabular}{|c|c|c|c|}
\hline Formulation & Physicochemical Characteristic & Activity & Reference \\
\hline $\begin{array}{l}\text { FA-chitosan-polycaprolactone } \\
\text { nanofibers }\end{array}$ & Size: $200-240 \mathrm{~nm}$ & $\begin{array}{l}\text { Antioxidant activity } \\
\text { Cytocompatible and able to provide sustained } \\
\text { Release of bioactive to support keratinocytes } \\
\text { growth in vitro non-hemolytic activity } \\
\text { Improve keratinocytes migration in vitro }\end{array}$ & [91] \\
\hline $\begin{array}{c}\text { FA-NC } \\
\text { nanocapsules based on poly }(\varepsilon \\
\text { caprolactone) polymer, loaded with FA }\end{array}$ & $\begin{array}{c}\text { Nanoparticles loaded with } \\
\text { hydroxycinnamic acids (HA-NCs) } \\
\text { have diameter of } 224-253 \mathrm{~nm}, \\
\text { encapsulation efficiency of } 53-78 \% \text {, } \\
\text { and are stable over time ( } 30 \text { days). } \\
\text { Zeta potential: }-7 \mathrm{mV} \\
\text { EE: } 62 \% \\
\text { pH: } 4.2 \\
\text { PDI: } 0.08 \\
\text { FA loaded amount: } 0.62 \mathrm{mg} / \mathrm{mL}\end{array}$ & $\begin{array}{l}\text { Protect the HAs in simulated gastric fluid } \\
\text { (SGF) and release them in simulated intestinal } \\
\text { fluid (SIF) }\end{array}$ & [92] \\
\hline
\end{tabular}

FA/CS-TPP NPs
chitosan-tripolyphosphate pentasodium
(CS-TPP) nanoparticles (NPs) with
ferulic acid
Microencapsulates of BSA with ferulic
acid-grafted chitosan

Cytocompatible and able to provide sustained Release of bioactive to support keratinocytes growth in vitro non-hemolytic activity Improve keratinocytes migration in vitro

\begin{tabular}{cc}
\hline $\begin{array}{c}\text { Chitosan-coated solid-lipid } \\
\text { nanoparticles }\end{array}$ & $\begin{array}{c}\text { Particle sizes: } 183 \pm 46 \text { and } \\
229 \pm 67 \mathrm{~nm}\end{array}$ \\
& $\begin{array}{c}\text { Encapsulation efficiency of } 80 \text { and } 78 \% \\
\text { Zeta potential of } 39.1 \text { and } 50.3 \mathrm{mV}\end{array}$ \\
\hline FA-cellulose acetate nanostructures & Average diameter of $760 \pm 130 \mathrm{~nm}$ \\
FA-Lewatit ${ }^{\circledR}$ & Changes in the FTIR-ATR peaks \\
$1685 / \mathrm{cm}(\mathrm{FA})$ \\
$1267 / \mathrm{cm}(\mathrm{C}=\mathrm{O})$ \\
Immobilize FA in the solid
\end{tabular}

FA-NA- $\varepsilon-P L-P V P$

Hyaluronan nanofibers and $\varepsilon$-polylysine mean thickness of $270 \pm 21 \mu \mathrm{m}$ and $273 \pm 41 \mu \mathrm{m}$
Antiproliferative activity against ME-180 cells

Primary absorption peak at 350 nm

$\uparrow$ Sustained-release effection

[94] Chemopreventive effects on 40-fold decreases
in dose of FA

against human pancreatic cancer cells MIA

PaCa-2 and Panc- 1

suppressed the growth of the tumor by $45 \%$; decrease expression of proliferation proteins

PCNA and MKI67; and also increased

expression of apoptotic proteins p-RB, p21 and $\mathrm{p}$-ERK $1 / 2$

Drug loading: $71.5 \%$
$\begin{gathered}\text { Average release of } 32 \mathrm{mg} \text { FA } / \mathrm{g} \text { of dry loaded } \\ \text { resin (recovery of } 22 \% \text { ) }\end{gathered}$

Innovative ophthalmic insert composed of

hyaluronan (HA) nanofibers for the dual

delivery of an antioxidant (ferulic acid, FA) and an antimicrobial peptide

( $\varepsilon$-polylysine, $\varepsilon$-PL) antibacterial activity:

Pseudomonas aeruginosa and Staphylococcus aureus 98]

FA-loaded G400E200-0 and G400E200-C hydrogels Hydrogels functionalized with the nitrogenous base cytosine for the controlled uptake and release of transferulic acid (TA)

\begin{tabular}{|c|c|c|c|}
\hline $\begin{array}{c}\text { Polymeric nanoparticles (NPs) } \\
\text { consisting of polylactic acid (NPA) and } \\
\text { poly(lactic-co-glycolic acid) (NPB) }\end{array}$ & $\begin{array}{c}\text { FA-NPAs: } \\
\text { Size: } 178 \mathrm{~nm} \\
\text { PDI: } 0.056 \\
\text { Zeta potential: }-33.7 \mathrm{mV} \\
\text { FA-NPBs: } \\
\text { Size: } 219 \mathrm{~nm} \\
\text { PDI: } 0.207 \\
\text { Zeta potential: }-23.80\end{array}$ & $\begin{array}{l}\text { Promising carriers for ocular } \\
\text { drug delivery }\end{array}$ & [101] \\
\hline $\begin{array}{l}\text { Self-microemulsifying drug } \\
\text { delivery system: } \\
\text { FA-loaded SMEDDS }\end{array}$ & Droplet size: $15.24 \mathrm{~nm}$ & $\begin{array}{c}\text { Oral bioavailability: } 185.96 \% \\
\text { Higher distribution in the brain and enhanced } \\
\text { serotonin levels in the brain } \\
\text { Extended the sleep time by } 2 \text {-fold and has } \\
\text { good stability }\end{array}$ & [102] \\
\hline
\end{tabular}


Table 1. Cont.

\begin{tabular}{|c|c|c|c|}
\hline Formulation & Physicochemical Characteristic & Activity & Reference \\
\hline $\begin{array}{l}\text { Zein-casein-lysine } \\
\text { protein-FA-nanoparticles }\end{array}$ & $\begin{array}{c}\text { Size: } 199 \mathrm{~nm} \\
\text { Zeta potential: }-26 \mathrm{mV}\end{array}$ & $\begin{array}{c}\text { Modulate the intestinal permeability of FA } \\
\text { Prolonged FA release } \\
\text { safe profile against Caco-2 and } \\
\text { HT29-MTX cells }\end{array}$ & [104] \\
\hline Combination FA and ZnO-NPs & No data & $\begin{array}{c}\text { Significant improvement in the elevated serum } \\
\text { creatinine and BUN and MDA concentrations } \\
\text { and expression of TNF- } \alpha \text {, Bax and caspase- } 3 \text { in } \\
\text { kidney tissues } \\
\text { Rise in the creatinine clearance, the activities } \\
\text { of catalase (CAT) and superoxide dismutase } \\
\text { (SOD) and the expression of HO-1, HIF- } 1 \alpha \\
\text { genes and proliferation marker (ki67) in } \\
\text { kidney tissues }\end{array}$ & [105] \\
\hline $\begin{array}{c}\text { PFA-DOX NPs } \\
\text { nanoparticles of poly(ferulic acid) } \\
\text { containing doxorubicin }\end{array}$ & No data & $\begin{array}{l}\text { Accumulation and retention at the tumor site } \\
\text { Superior tumor suppression. } \\
\text { Improving safety } \\
\text { Reduced the physical toxicity of free DOX }\end{array}$ & [106] \\
\hline $\begin{array}{l}\text { FA-grafted curdlan conjugate } \\
\text { (Cur-D-g-FA) }\end{array}$ & $\begin{array}{c}\text { Zeta potential: } \\
-22.57-(-34.87) \mathrm{mV}\end{array}$ & $\begin{array}{l}\text { Favorable bioaccessibility of } \mathrm{BC} \text { in vitro } \\
\text { oxidation stability }\end{array}$ & [108] \\
\hline
\end{tabular}

\section{Prodrugs of FA}

Prodrugs are substances that are administered in a pharmacologically inactive form, and after administration, they are metabolized in vivo into the active drugs. When developing prodrugs, researchers focus on the optimization of the absorption, distribution, metabolism and excretion (ADME) properties. An important feature of biologically active substances is their ability to permeate across biological barriers, including getting into the CNS by crossing the blood-brain barrier (BBB). It was observed that amide-based prodrugs of ferulic acid with an aromatic ring were effectively bound to the L-type amino acid transporter (LAT1) (Figure 3) and used the transporter for cellular uptake in vitro and crossed the BBB after in situ perfusion in mice [110]. The amide prodrug with the promoiety directly conjugated in the meta-position to ferulic acid underwent the bioconversion to the parent drug in mouse brain. It is worth noting that the analogous ester-based prodrug did bind to LAT1 but did not utilize the transporter for cellular uptake in ARPE-19 cells. However, the presence of an ester linker between the prodrug and the parent drug promoted favorable bioconversion properties in humans.<smiles>COc1cc(/C=C/C(=O)NCc2cccc(CC(N)C(=O)O)c2)ccc1O</smiles><smiles>COc1cc(/C=C/C(=O)Nc2cccc(CC(N)C(=O)O)c2)ccc1O</smiles><smiles>COc1cc(/C=C/C(=O)Oc2cccc(CC(N)C(=O)O)c2)ccc1O</smiles>

Figure 3. Chemical structures of FA prodrugs based on L-type aminoacids. 
A new amino acid-based prodrug for simultaneous intestinal release of silybin and ferulic acid was developed by the team of Trombino et al. [111]. The carrier for the synthesized 1-phenylalanine- $N$-(4-hydroxy-3-methoxyphenyl) prop-2-en-O-(2R,3R)-3,5,7-trihydroxy2-((2R,3R)-3-(4-hydroxy-3-methoxyphenyl)-2-(hydroxymethyl)-2,3-dihydro-benzo-(1,4)-dioxin6-yl)croman-4-one was 1-phenylalanine, which has an intrinsic chemical reactivity due to the presence of an amine group, placed on the chiral center, and a carboxylic group. Ferulic acid is attached to the amine group of the amino acid by the amide bond (Figure 4). The obtained prodrug demonstrated high antioxidant activity under simulated physiological conditions; therefore, this method might be used for improving therapeutic potential of other highly reactive and poorly water-soluble biological substances.

(A)<smiles>COc1cc(/C=C/C(=O)NC(Cc2ccccc2)C(=O)OCC2Oc3ccc(C4Oc5cc(O)cc(O)c5C(=O)C4O)cc3OC2c2ccc(O)c(OC)c2)ccc1O</smiles>

(B)<smiles>COc1cc(/C=C/C(=O)NC(C)C(=O)N2CCCC2C(=O)O)ccc1OC/C=C(\C)CCC=C(C)C</smiles>

Figure 4. Chemical structures of (A) 1-phenylalanine-N-(4-hydroxy-3-methoxyphenyl) prop-2en-O-(2R,3R)-3,5,7-trihydroxy-2-((2R,3R)-3-(4-hydroxy-3-methoxyphenyl)-2-(hydroxymethyl)-2,3dihydro-benzo-(1,4)-dioxin-6-yl)croman-4-one and (B) 3-(4'geranyloxy-3'-methoxyphenyl)-2-transpropenoyl-L-alanyl-L-proline.

Another compound of this group is GAP, a new prodrug of known chemopreventive agent used in the treatment of colon cancer, namely 3-(4'geranyloxy-3'-methoxyphenyl)-2trans-propenic acid (Figure 4), which was investigated by Reference [112]. The results of this study clearly indicate that GAP effectively inhibited colitis-related colon carcinogenesis in mice with no side effects. Dietary GAP had a modulatory effect on cell proliferation by alleviating the oxidative stress (lowering tissue expression and urinary level of 8$\mathrm{OHdG}$ ) and enhancing expression of the antioxidant enzyme HO-1. The prodrug of $4^{\prime}$-geranyloxyferulic acid was designed to be hydrolyzed by the intestinal exopeptidase, which specifically hydrolyzes the last peptide bond in tripeptides in which + -Ala (or Gly) and L-pro occupy the second last and last positions, respectively.

Tan et al. [113] designed new PtIV prodrugs of oxoplatin (cis,cis,cis-[ $\left.\left[\mathrm{PtCl}_{2}\left(\mathrm{NH}_{3}\right)_{2}(\mathrm{OH})_{2}\right]\right)$, [PtIVCl $\left.2\left(\mathrm{NH}_{3}\right)_{2}\left(\mathrm{O}_{2} \mathrm{C}-\mathrm{FA}\right)_{2}\right](\mathrm{Pt}-2)$ and [ $\left.\mathrm{PtIVCl}_{2}\left(\mathrm{NH}_{3}\right)_{2}\left(\mathrm{O}_{2} \mathrm{C}-\mathrm{RH}\right)_{2}\right](\mathrm{Pt}-3)$, by conjugating oxoplatin with ferulic acid and rhein, which have well-known biological activities. Antitumor activity of the new complex compound towards lung cancer cells (A549) and lung cancer xenograft mice model cells (A549/DPP) was higher (67.45\% of inhibition) than that of 
cisplatin (33.05\% of inhibition). What is more, the highest concentration of the prodrug was observed in the mitochondria; thus, the proposed anticancer strategy may be a promising approach to personalized anticancer therapy.

There is also research on new phenolipids with amphiphilic properties. Ferulic acid was esterified with butanol to produce butyl ferulate, which was further dihydroxylated, followed by esterification with butyric anhydride to produce a phenolipid containing butyric acid. The obtained phenolipid showed higher antioxidant activity than the substrate (evaluated by the linoleic acid oxidation method) [114].

\section{Conclusions}

Ferulic acid demonstrates multiple pharmacological activities, evaluated both in vitro and in vivo. It has anti-inflammatory and antitumor properties, as well as antidepressant and hepatoprotective ones. Its strong antioxidant activity is used, among others, in the food industry, dermatology and cosmetology. Nevertheless, due to the low lipophilicity, clinical and industrial applications of ferulic acid are limited. Therefore, there is a search for new forms of its delivery in order to increase its bioavailability and a possibility of practical use. The methods of functionalization of ferulic acid include the preparation of prodrugs of FA and development of innovative ways of its delivery. Polysaccharide-based matrices and polymeric nanoparticles are tested as the delivery vehicles. There are developed hydrogels and encapsulates with ferulic acid based on cellulose acetate, hyaluronates, glycerin, dihydroxyaluminum aminoacetate, tartaric acid, lipid nanoparticles and nanoparticles of precious metals, such as gold, which have interesting therapeutic properties.

Author Contributions: Conceptualization and methodology, M.S.-G.; writing—original draft preparation, M.S.-G.; writing-review and editing, M.S.-G. and M.M.; visualization, M.S.-G.; project administration, M.S.-G. All authors have read and agreed to the published version of the manuscript.

Funding: Monika Stompor-Goracy acknowledges support from the National Science Centre NCN Poland, Grant SONATA 16 number 2020/39/D/NZ9/02023) and also would like to thank the Polish Ministry of Science and Higher Education (currently Polish Ministry of Education and Science) for the financial support under the MNiSW scholarship for outstanding young researchers (STYP/15/0763/E-546/2020). The funders had no role in study design, data collection and analysis, decision to publish or preparation of the manuscript.

Institutional Review Board Statement: Not applicable.

Informed Consent Statement: Not applicable.

Data Availability Statement: Data are contained within the article.

Conflicts of Interest: The authors declare no conflict of interest.

\section{References}

1. Stompor, M.; Żarowska, B. Antimicrobial activity of xanthohumol and its selected structural analogues. Molecules 2016, 21, 608. [CrossRef]

2. Panek-Krzyśko, A.; Stompor-Goracy, M. The pro-health benefits of morusin administration-An update review. Nutrients 2021, 13, 3043. [CrossRef]

3. Stompor-Goracy, M.; Bajek-Bil, A.; Machaczka, M. Chrysin: Perspectives on contemporary status and future possibilities as pro-health agent. Nutrients 2021, 13, 2038. [CrossRef]

4. Stompor, M.; Świtalska, M.; Wietrzyk, J. The influence of a single and double biotinylation of xanthohumol on its anticancer activity. Acta Bioch. Pol. 2019, 66, 2876. [CrossRef]

5. Stompor, M. 6-Acetamidoflavone obtained by microbial and chemical methods and its antioxidant activity. J. Biotechnol. 2016, 237, 25-34. [CrossRef]

6. Lyashenko, S.; Fabrikov, D.; González-Fernández, J.M.; Gómez-Mercado, F.; Ruiz, R.L.; Fedorov, A.; de Bélair, G.; Urrestarazu, M.; Rodríguez-García, I.; Alvarez-Corral, M.; et al. Phenolic composition and in vitro antiproliferative activity of Borago ssp. seed extracts on HT-29 cancer cells. Food Biosci. 2021, 42, 101043. [CrossRef]

7. Yadav, M.P.; Kaur, A.; Singh, B.; Simon, S.; Kaur, N.; Powell, M.; Sarker, M. Extraction and characterization of lipids and phenolic compounds from the brans of different wheat varieties. Food Hydrocoll. 2021, 117, 106734. [CrossRef] 
8. Turghun, C.; Bakri, M.; Liu, G.Y.; Bobakulov, K.; Aisa, H.A. Phenolic glycosides from Nitraria sibirica leaves and their in vitro biological activities. Nat. Prod. Res. 2021, 35, 1388-1392. [CrossRef]

9. Drawbridge, P.C.; Apea-Bah, F.; Silveira Hornung, P.; Beta, T. Bioaccessibility of phenolic acid in Canadian hulless barley varieties. Food Chem. 2021, 358, 129905. [CrossRef]

10. Wu, S.; Shen, D.; Wang, R.; Li, Q.; Mo, R.; Zheng, Y.; Zhou, Y.; Liu, Y. Phenolic profiles and antioxidant activities of free, esterified and bound phenolic compounds in walnut kernel. Food Chem. 2021, 350, 129217. [CrossRef]

11. Zhang, M.; Xu, Y.; Xiang, J.; Zheng, B.; Yuan, Y.; Luo, D.; Fan, J. Comparative evaluation on phenolic profiles, antioxidant properties and $\alpha$-glucosidase inhibitory effects of different milling fractions of foxtail millet. J. Cereal Sci. 2021, 99, 103217. [CrossRef]

12. Naveen, J.; Baskaran, R.; Baskaran, V. Profiling of bioactives and in vitro evaluation of antioxidant and antidiabetic property of polyphenols of marine algae Padina tetrastromatica. Algal Res. 2021, 55, 102250. [CrossRef]

13. Joshi, P.; Joshi, S.; Semwal, D.K.; Bisht, A.; Sharma, S.; Dwivedi, J. Chemical composition, antioxidative and antimicrobial activities of turmeric spent oleoresin. Ind. Crop. Prod. 2021, 162, 113278. [CrossRef]

14. Peighambardoust, S.H.; Jafarzadeh-Moghaddam, M.; Pateiro, M.; Lorenzo, J.M.; Domínguez, R. Physicochemical, thermal and rheological properties of pectin extracted from sugar beet pulp using subcritical water extraction process. Molecules 2021, 26, 1413. [CrossRef]

15. Ozkok, A.; Keskin, M.; Tanugur Samanci, A.E.; Yorulmaz Onder, E.; Takma, C. Determination of antioxidant activity and phenolic compounds for basic standardization of Turkish propolis. Appl. Biol. Chem. 2021, 64, 37. [CrossRef]

16. Zhu, S.; Bai, X.; Zhu, J.; Li, W.; Wang, B. Multi-spectral techniques and molecular docking to investigation of the interaction between ferulic acid and pepsin. Spectrochim. Acta A Mol. Biomol. Spectr. 2021, 251, 119442. [CrossRef]

17. Yang, J.; Chen, J.; Hao, Y.; Liu, Y. Identification of the DPPH radical scavenging reaction adducts of ferulic acid and sinapic acid and their structure-antioxidant activity relationship. LWT 2021, 146, 111411. [CrossRef]

18. Grzelczyk, J.; Budryn, G.; Peña-García, J.; Szwajgier, D.; Gałązka-Czarnecka, I.; Oracz, J.; Pérez-Sácnchez, H. Evaluation of the inhibition of monoamine oxidase A by bioactive coffee compounds protecting serotonin degradation. Food Chem. 2021, 348, 129108. [CrossRef]

19. Chen, J.; Lin, D.; Zhang, C.; Li, G.; Zhang, N.; Ruan, L.; Yan, Q.; Li, J.; Yu, X.; Xie, X.; et al. Antidepressant-like effects of ferulic acid: Involvement of serotonergic and norepinergic systems. Metab. Brain Dis. 2014, 30, 129-136. [CrossRef]

20. Choi, J.H.; Park, J.K.; Kim, K.M.; Lee, H.J.; Kim, S. In vitro and in vivo antithrombotic and cytotoxicity effects of ferulic acid. J. Biochem. Mol. Toxicol. 2018, 32, e22004. [CrossRef]

21. Sun, X.; Sun, P.; Liu, L.; Jiang, P.; Li, Y. Ferulic acid attenuates microglia-mediated neuroinflammation in retinal degeneration. BMC Ophthalmol. 2021, 21, 13. [CrossRef]

22. $\mathrm{Wu}, \mathrm{X}$.; Lin, L.; Wu, H. Ferulic acid alleviates lipopolysaccharide-induced acute lung injury through inhibiting TLR4/NF-kB signaling pathway. J. Biochem. Mol. Toxicol. 2021, 35, e22664. [CrossRef]

23. Yasmin, S.; Cercjia, C.; Badavath, V.N.; Laghezza, A.; Dal Piaz, F.; Mondal, S.K.; Atli, O.; Baysal, M.; Vadielan, S.; Shankar, S.; et al. A series of ferulic acid amides reveals unexpected peroxiredoxin 1 inhibitory activity with in vivo antidiabetic and hypolipidemic effects. ChemMedChem 2021, 16, 484-498. [CrossRef]

24. Zhang, L.W.; Al-Suwayeh, S.A.; Hsieh, P.W.; Fang, J.Y. A comparison of skin delivery of ferulic acid and its derivatives: Evaluation of their efficacy and safety. Int. J. Pharm. 2010, 399, 44-51. [CrossRef]

25. Andrade, S.; Ramalho, M.J.; Lureiro, J.A.; Pereira, M.C. The biophysical interaction of ferulic acid with liposomes as biological membrane model: The effect of the lipid bilayer composition. J. Mol. Liq. 2021, 324, 114689. [CrossRef]

26. Wei, Z.; Xue, Y.; Xue, Y.; Cheng, J.; Lv, G.; Chu, L.; Ma, Z.; Guan, S. Ferulic acid at-tenuates non-alcoholic steatohepatitis by reducing oxidative stress and inflammation through inhibition of the ROCK/NF-kB signaling pathways. J. Pharmacol. Sci. 2021, 147, 72-80. [CrossRef]

27. Shi, Y.; Chen, X.; Qiang, S.; Su, J.; Li, J. Anti-oxidation and anti-inflammatory po-tency evaluation of ferulic acid derivatives obtained through virtual screening. Int. J. Mol. Sci. 2021, 22, 11305. [CrossRef]

28. Perumal, E.; Eswaran, S.; Parvin, R.; Balasubramanian, S. Mitigation of arsenic induced developmental cardiotoxicity by ferulic acid in zebrafish. Comperativ. Biochem. Physiol. C Toxicol. Pharmacol. 2021, 244, 109021. [CrossRef]

29. Yu, C.; Pan, S.; Zhang, J.; Li, X.; Niu, Y. Ferulic acid exerts Nrf2-dependent protection against prenatal lead exposure-induced cognitive impairment in offspring mice. J. Nutr. Biochem. 2021, 91, 108603. [CrossRef]

30. Kassab, R.B.; Lokman, M.S.; Daabo, H.M.A.; Gaber, D.A.; Habotta, O.A.; Hafez, M.M.; Zhery, A.S.; Moneim, A.E.A.; Fouda, M.S. Ferulic acid influences Nrf2 activation to restore testicular tissue from cadmium-induced oxidative challenge, inflammation, and apoptosis in rats. J. Food Biochem. 2020, 44, e13505. [CrossRef]

31. Guvvala, P.R.; Ravindra, J.P.; Selvaraju, S.; Arangasamy, A.; Venkata, K.M. Ellagic and ferulic acids protect arsenic-induced male reproductive toxicity via regulating Nfe212, Ppargc1a and StAR expressions in testis. Toxicology 2019, 413, 1-12. [CrossRef]

32. Kim, H.Y.; Park, J.; Lee, K.H.; Lee, D.U.; Kwak, J.H.; Kim, Y.S.; Lee, S.M. Ferulic acid protects against carbon tetrachloride-induced liver injury in mice. Toxicology 2011, 282, 104-111. [CrossRef] [PubMed]

33. Aswar, U.; Mahajan, U.; Kandhare, A.; Aswar, M. Ferulic acid ameliorates doxorubicin-induced cardiac toxicity in rats. NaunynSchmiedeberg's Arch. Pharmacol. 2019, 392, 659-668. [CrossRef] [PubMed] 
34. Bami, E.; Ozakpinar, O.B.; Ozdemir-Kumral, Z.N.; Köroglu, K.; Ercan, F.; Cirakli, Z.; Sekerler, T.; Izzettin, F.V.; Sancar, M.; Okuyan, B. Protective effect of ferulic acid on cisplatin induced nephrotoxicity in rats. Environ. Toxicol. Pharmacol. 2017, 54, 105-111. [CrossRef] [PubMed]

35. Jain, P.G.; Mahajan, U.B.; Shinde, S.D.; Surana, S.J. Cardioprotective role of FA against isoproterenol induced cardic toxicity. Mol. Biol. Rep. 2018, 45, 1357-1365. [CrossRef]

36. Kelainy, E.G.; Laila, I.M.I.; Ibrahim, S.R. The effect of ferulic acid against lead-induced oxidative stress and DNA damage in kidney and testes of rats. Environ. Sci. Poll. Res. 2019, 26, 31675-31684. [CrossRef]

37. Ma, Y.; Chen, K.; Lv, L.; Wu, S.; Guo, Z. Ferulic acid ameliorates nonalcoholic fatty liver disease and modulates the gut microbiota composition in high-fat diet fed ApoE ${ }^{-1-}$ mice. Biomed. Pharmacother. 2019, 113, 108753. [CrossRef]

38. Xu, T.; Song, Q.; Zhou, L.; Yang, W.; Wu, X.; Qian, Q.; Chai, H.; Han, Q.; Pan, H.; Dou, X.; et al. Ferulic acid alleviates lipotoxicityinduced hepatocellular death through the SIRT1-regulated autophagy pathway and independently of AMPK and Akt in AML-12 hepatocytes. Nutr. Metabol. 2021, 18, 13. [CrossRef]

39. Liu, Z.; Ma, Z.; Zhang, H.; Summah, B.S.; Liu, H.; An, D.; Zhan, Q.; Lai, W.; Zeng, Q.; Ren, H.; et al. Ferulic acid increases intestinal Lactobacillus and improves cardiac function in TCA mice. Biomed. Pharmacother. 2019, 120, 109482. [CrossRef]

40. Salau, V.; Erukainure, O.L.; Koorbanally, N.A.; Islam, S. Ferulic acid promotes muscle glucose uptake and modulate dysregulated redox balance and metabolic pathway in ferric-induced pancreatic oxidative injury. J. Food Biochem. 2021, e13641. [CrossRef]

41. Cao, L.; Li, Z.; Yang, Z.; Wang, M.; Zhang, W.; Ren, Y.; Li, L.; Hu, J.; Sun, Z.; Nie, S. Ferulic acid positively modulates the inflammatory response to septic liver injury through the GSK-3ß/NF-kB/CREB pathway. Life Sci. 2021, 277, 119584. [CrossRef] [PubMed]

42. Sevgi, K.; Tepe, B.; Sarikurkcu, C. Antioxidant and DNA damage protection potentials of selected phenolic acids. Food Chem. Toxicol. 2015, 77, 12-21. [CrossRef] [PubMed]

43. Nakayama, H.; Nakahara, M.; Matsugi, E.; Soda, M.; Hattori, T.; Hara, K.; Usami, A.; Kusumoto, C.; Higashiyama, S.; Kitaichi, K Protective Effect of Ferulic Acid against Hydrogen Peroxide Induced Apoptosis in PC12 Cells. Molecules 2021, 26, 90. [CrossRef]

44. Ani, G.; Tanya, T.Y.; Reneta, T. Antitumor and Protective effect of ferulic acid against hydrogen peroxide induced apoptosis in PC12 cells apoptogenic effects of ferulic acid on cervical carcinoma cells. Res. J. Biotechnol. 2021, 16, 6-11.

45. Zhang, X.; Lin, D.; Jiang, R.; Li, H.; Wan, J.; Li, H. Ferulic acid antitumor activity and inhibits metastasis in breast cancer cells by regulating epithelial to mesenchymal transition. Oncol. Rep. 2016, 36, 271-278. [CrossRef]

46. Helmy, S.A.; El-Mofty, S.; El Gayar, A.M.; El-Sherbiny, I.M.; El-Far, Y.M. Novel doxorubicin/folate-targeted trans-ferulic acidloaded doxorubicin/folate-targeted trans-ferulic acid-loaded PLGA nanoparticles combination: In vivo superiority over the standard chemotherapeutic regimen for breast cancer treatment. Biomed. Pharmacother. 2022, 145, 112376. [CrossRef]

47. Caparica, R.; Júlio, A.; Baby, A.R.; de Almeida, T.S.; Costa, J.G. In vitro cytotoxicity assessment of ferulic, caffeic and $p$-coumaric acids on human renal cancer cells. Biomed. Biopharm. Res. 2020, 17. [CrossRef]

48. Karimvand, M.N.; Kalantar, H.; Khodayar, M.J. Cytotoxic and apoptotic effects of ferulic acid on renal carcinoma cell line (ACHN). Jundishapur J. Nat. Pharm. Prod. 2021, 15, e81969. [CrossRef]

49. Peng, C.C.; Chyau, C.C.; Wang, H.E.; Chang, C.H.; Chen, K.C.; Chou, K.Y.; Peng, R.Y. Cytotoxicity of ferulic acid on T24 cell line differentiated by different microenvironments. BioMed Res. Int. 2013, 2013, 579859. [CrossRef]

50. Wang, T.; Gong, X.; Jiang, R.; Li, H.; Du, W.; Kuang, G. Ferulic acid inhibits proliferation and promotes apoptosis via blockage of PI3K/Akt pathway in osteosarcoma cell. Am. J. Transl. Res. 2016, 8, 968-980.

51. ElKhazendar, M.; Chalak, J.; El-Huneidi, W.; Vinod, A.; Abdel-Rahman, W.M.; Abu-Gharbieh, E. Antiproliferative and proapoptotic activities of ferulic acid in breast and liver cancer cell lines. Trop. J. Pharm. Res. 2019, 18, 2571-2576.

52. Gao, J.; Yu, H.; Guo, W.; Kong, Y.; Gu, L.; Li, Q.; Yang, S.; Zhang, Y.; Wang, Y. The anticancer effects of ferulic acid is associated with induction of cell cycle arrest and autophagy in cervical cancer cells. Cancer Cell 2018, 18, 102. [CrossRef] [PubMed]

53. Bouzaiene, N.N.; Kilani Jaziri, S.; Kovacic, H.; Chekir-Ghedira, L.; Ghedira, K.; Luis, J. The effects of caffeic, coumaric and ferulic acids on proliferation, superoxide production, adhesion and migration of human tumor cells in vitro. Eur. J. Pharmacol. 2015, 766, 99-105. [CrossRef] [PubMed]

54. Cheng, W.J.; Zhang, P.P.; Luo, Q.Q.; Deng, S.M.; Jia, A.Q. The chemosensitizer ferulic acid enhances epirubicin-induced apoptosis in MDA-MB-231 cells. J. Funct. Foods 2020, 73, 104130. [CrossRef]

55. Das, U.; Manna, K.; Adhikary, A.; Mishra, S.; Saha, K.D.; Sharma, R.D.; Majumder, B.; Dey, S. Ferulic acid enhances the radiation sensitivity of lung and liver carcinoma cells by collapsing redox homeostasis: Mechanistic involvement of Akt/p38 MAPK signalling pathway. Free Rad. Res. 2019, 53, 944-967. [CrossRef]

56. Wang, F.; Lu, W.; Zhang, T.; Dong, J.; Gao, H.; Li, P.; Wang, S.; Zhang, J. Development of novel ferulic acid derivatives as potent histone deacetylase inhibitors. Bioorg. Med. Chem. 2013, 21, 6973-6980. [CrossRef]

57. Borges, A.; Ferreira, C.; Saavedra, M.J.; Simyẽos, M. Antibacterial activity and mode of action of ferulic and gallic acids against pathogenic bacteria. Microb. Drug Resist. 2013, 19, 256-265. [CrossRef]

58. Zhou, Z.; Shi, T.; Hou, J.; Li, M. Ferulic acid alleviates atopic dermatitis-like symptoms in mice via its potent anti-inflammatory effect. Immunopharmacol. Immunotoxicol. 2020, 42, 1-10. [CrossRef]

59. Peres, D.D.; Sarruf, F.D.; De Oliveira, C.A.; Velasco, M.V.R.; Baby, A.R. Ferulic acid photoprotective properties in association with UV filters: Multifunctional sunscreen with improved SPF and UVA-PF. J. Photochem. Photobiol. B 2018, 185, 46-49. [CrossRef]

60. Ren, Z.; Zhang, R.; Li, Y.; Li, Y.; Yang, Z.; Yang, H. Ferulic acid exerts neuroprotective effects against cerebral ischemia/reperfusioninduced injury via antioxidant and anti-apoptotic mechanisms in vitro and in vivo. Int. J. Mol. Med. 2017, 40, 1444-1456. [CrossRef] 
61. Narasimhan, A.; Chinnaiyan, M.; Karundevi, B. Ferulic acid exerts its antidiabetic effect by modulating insulin-signalling molecules in the liver of high-fat diet and fructose-induced type-2 diabetic adult male rat. Appl. Physiol. Nutr. Metab. 2015, 40, 769-781. [CrossRef] [PubMed]

62. Prabhakar, P.K.; Prasad, R.; Ali, S.; Doble, M. Synergistic interaction of ferulic acid with commercial hypoglycemic drugs in streptozotocin induced diabetic rats. Phytomedicine 2013, 20, 488-494. [CrossRef] [PubMed]

63. Ijabadeniyi, O.A.; Govender, A.; Olagunju, O.F.; Oyedeji, A.B. The antimicrobial activity of two phenolic acids against foodborne Escherichia coli and Listeria monocytogenes and their effectiveness in a meat system. Ital. J. Food Sci. 2021, 33, 39-45. [CrossRef]

64. Shen, R.; Wang, H.; Wu, K.; Gao, J.; Li, J. Characterization and antimicrobial properties of ferulic acid grafted self-assembled bacterial cellulose-chitosan membranes. J. Appl. Polym. Sci. 2021, 138, 50824. [CrossRef]

65. Liu, W.; Xie, J.; Li, L.; Xue, B.; Li, X.; Gan, J.; Shao, Z.; Sun, T. Properties of phenolic acid-chitosan composite films and preservative effect on Penaeus vannamei. J. Mol. Sci. 2021, 1239, 130531. [CrossRef]

66. Bacanli, M.; Aydin, S.; Taner, G.; Göktaş, H.G.; Sahin, T.; Başaran, A.A.; Başaran, N. The protective role of ferulic acid on sepsis-induced oxidative damage in Wistar albino rats. Environ. Toxicol. Pharmacol. 2014, 38, 774-782. [CrossRef]

67. Yu, Q.; Fan, L. Understanding the combined effect and inhibition mechanism of 4-hydroxycinnamic acid and ferulic acid as tyrosinase inhibitors. Food Chem. 2021, 352, 129369. [CrossRef]

68. Qi, D.; Li, Q.; Chen, C.; Wang, X. Ferulic acid modification enhances the anti-oxidation activity of natural Hb in vitro. Artif. Cell Nanomed. Biotechnol. 2018, 46, 1191-1199. [CrossRef]

69. Yao, N.; Sun, S. Hydrophilic glyceryl ferulates preparation catalyzed by free lipase b from Candida antartica. J. Oleo Sci. 2020, 69, 43-53. [CrossRef]

70. Oehlke, K.; Behsnilian, D.; Mayer-Miebach, E.; Weidler, P.G.; Greiner, R. Edible solid lipid nanoparticles (SLN) as carriers system for antioxidants of different lipophilicity. PLOS ONE 2017, 12, e0171662. [CrossRef]

71. Waibel, J.S.; Rudnick, A. Laser assisted delivery to treat facial scars. Facinal Plast. Surgey Clin. N. Am. 2017, 25, 105-117. [CrossRef] [PubMed]

72. Waibel, J.S.; Mi, Q.S.; Ozog, D.; Qu, L.; Zhou, L.; Rudnick, A.; Al-Niaimi, F.; Woodward, J.; Campos, V.; Mordon, S. Laser-assisted delivery of vitamin $\mathrm{C}$, vitamin $\mathrm{E}$, and ferulic acid formula serum decreases fractional laser postoperative recovery by increased beta fibroblast growth factor expression. Laser Surg. Med. 2016, 48, 238-244. [CrossRef] [PubMed]

73. Yang, B.; Du, S.; Bai, J.; Shang, K.; Lu, Y.; Li, P. Studies on transdermal delivery of ferulic acid through rat skin treated by microneedle arrays. China J. Chin. Mater. Med. 2014, 39, 4773-4777.

74. Bai, J.; Lu, Y.; Li, P.Y.; Liu, C.M.; Wu, H.C.; Wen, R.; Du, S.Y. Development and in vitro evaluation of a transdermal hydrogel patch for ferulic acid. Pak. J. Pharm. Sci. 2014, 27, 369-375. [PubMed]

75. Tao, L.; He, L.F.; Guan, Y.M.; Chen, L.H.; Zhu, W.F.; Jin, C.; Wu, L. Preparation and transdermal permeation of triptolide and ferulic acid ethosomes gel in vitro. Zhongguo Zhongyao Zazhi 2018, 43, 1139-1144.

76. Hassanzadeh, P.; Arbabi, E.; Rostami, F.; Atyabi, F.; Dinarvand, R. Aerosol delivery of ferulic acid-loaded nanostructured lipid carriers: A promising treatment approach against the respiratory disorders. Physiol. Pharmacol. 2017, 21, 331-342.

77. Del Olmo, N.S.; González, C.E.P.; Rojas, J.D.; Gómez, R.; Ortega, P.; Escarpa, A.; de la Mata, F.J. Antioxidant and antibacterial properties of carbosilane dendrimers functionalized with polyphenolic moieties. Pharmaceutics 2021, 12, 698. [CrossRef]

78. Anbazhagan, R.; Muthusamy, G.; Krishnamoorthi, R.; Kumaresan, S.; Prasad, N.R.; Lai, J.Y.; Yang, J.M.; Tsai, H.C. PAMAM G 4.5 dendrimers for targeted delivery of ferulic acid and paclitaxel to overcome P-glycoprotein-mediated multidrug resistance. Biotechnol. Bioeng. 2021, 118, 1213-1223. [CrossRef]

79. Vashisth, P.; Sharma, M.; Nikhil, K.; Singh, H.; Panwar, R.; Pruthi, P.A.; Pruthi, V. Antiproliferative activity of ferulic acid-encapsulated electrospun PLGA/PEO nanofibers against MCF-7 human breast carcinoma cells. 3 Biotech 2015, 5, 303-315. [CrossRef]

80. Rajendran, I.; Ponrasu, T.; Rajaram, R.; Suguna, L. The apoptotic effect of ferulic acid-synthesized gold nanoparticles against human epidermoid carcinoma (A431) cells via activation of caspase-3 pathway. J. Drug Deliv. Sci. Technol. 2021, 63, 102478. [CrossRef]

81. Johnson, E.M.; Lee, H.; Jayabalan, R.; Suh, J.W. Ferulic acid grafted self-assembled fructo-oligosaccharide micro particle for targeted delivery to colon. Carbohyd. Polym. 2020, 247, 116550. [CrossRef]

82. Casadey, R.; Broglia, M.; Barbero, C.; Criado, S.; Rivarola, C. Controlled release systems of natural phenolic antioxidants encapsulated inside biocompatible hydrogels. React. Funct. Polym. 2020, 156, 104729. [CrossRef]

83. Rezaeiroshan, A.; Saeedi, M.; Morteza-Semnani, K.; Akbari, J.; Gahsemi, M.; Nokhodchi, A. development of trans-ferulic acid niosome: An optimization and an in-vivo study. J. Drug Deliv. Sci. Technol. 2020, 59, 101854. [CrossRef]

84. Hassanzadeh, P.; Arbabi, E.; Rostami, F. Coating of ferulic acid-loaded silk fibroin nanoparticles with neutrophil membranes: A promising strategy against the acute pancreatitis. Life Sci. 2021, 270, 119128. [CrossRef] [PubMed]

85. Wang, C.Y.; Hsiao, C.Y.; Tsai, K.L.; Cheng, Y.H. Injectable thermosensitive chitosan-based hydrogel containing ferulic acid for treating peripheral arterial disease. J. Tissue Eng. Regen. Med. 2020, 14, 1438-1448. [CrossRef] [PubMed]

86. Telange, D.R.; Jain, S.P.; Pethe, A.M.; Kharkar, P.S.; Rarokar, N.R. Use of combined nanocarrier system based on chitosan nanoparticles and phospholipids complex for improved delivery of ferulic acid. Int. J. Biol. Macromol. 2021, 171, 288-307. [CrossRef]

87. Dhayanandamoorthy, Y.; Antoniraj, M.G.; Kandregula, C.A.B.; Kandasamy, R. Aerosolized hyaluronic acid decorated, ferulic acid loaded chitosan nanoparticle: A promising asthma control strategy. Int. J. Pharm. 2020, 591, 119958. [CrossRef] [PubMed] 
88. Li, C.; Fang, K.; He, W.; Li, K.; Jiang, Y.; Li, J. Evaluation of chitosan-ferulic acid microcapsules for sustained drug delivery: Synthesis, characterizations, and release kinetics in vitro. J. Mol. Sci. 2021, 1227, 129353. [CrossRef]

89. Mancuso, A.; Cristiano, M.C.; Pandolfo, R.; Greco, M.; Fresta, M.; Paolino, D. Improvement of ferulic acid antioxidant activity by multiple emulsions: In vitro and in vivo evaluation. Nanomaterials 2021, 11, 425. [CrossRef] [PubMed]

90. Praphakar, R.A.; Munusamy, M.A.; Rajan, M. Development of extended-voyaging anti-oxidant linked amphiphilic polymeric nanomicells for anti-tuberculosis drug delivery. Int. J. Pharm. 2017, 524, 168-177. [CrossRef] [PubMed]

91. Poornima, B.; Korrapati, P.S. Fabrication of chitosan-polycaprolactone composite nanofibrous scaffold for simultaneous delivery of ferulic acid and resveratrol. Carbohydr. Polym. 2017, 157, 1741-1749. [CrossRef] [PubMed]

92. Granata, G.; Consoli, G.M.L.; Lo Nigro, R.; Geraci, C. Hydroxycinnamic acids loaded in lipid-core nanocapsules. Food Chem. 2018, 245, 551-556. [CrossRef] [PubMed]

93. Panwar, R.; Sharma, A.K.; Kaloti, M.; Dutt, D.; Pruthi, V. Characterization and anticancer potential of ferulic acid-loaded chitosan nanoparticles against ME-180 human cervical cancer cell lines. Appl. Nanosci. 2016, 6, 803-813. [CrossRef]

94. Li, C.; Li, J.B. Preparation of chitosan-ferulic acid conjugate: Structure characterization and in the application of pharmaceuticals. Int. J. Biol. Macromol. 2017, 105, 1539-1543. [CrossRef]

95. Thakkar, A.; Chenreddy, S.; Wang, J.; Prabhu, S. Ferulic acid combined with aspirin demonstrates chemopreventive potential towards pancreatic cancer when delivered using chitosan-coated solid-lipid nanoparticles. Cell Biosci. 2015, 5, 46. [CrossRef] [PubMed]

96. Duarte, F.I.C.; Costa, A.B.S.M.; Filho, J.F.V.; Freite, V.L.P.; Freire, J.V.A.; Converti, A.; Ferrari, M.; Gomes, A.P.B.; Ostrosky, E.A.; Lima, Á.A.N. In vitro release studies of ferulic acid in semi-solid formulations with optimized synthetic membrane. J. Drug Deliv. Sci. Technol. 2021, 61, 102106. [CrossRef]

97. Hou, J.; Yang, J.; Zheng, X.; Wang, M.; Liu, Y.; Yu, D.G. A nanofiber-based drug depot with high drug loading for sustained release. Int. J. Pharm. 2020, 583, 119397. [CrossRef]

98. Martins, G.N.; Spínola, V.; Castilho, P.C. Release of adsorbed ferulic acid in simulated gastrointestinal conditions. Eur. Food Res. Technol. 2020, 246, 1297-1306. [CrossRef]

99. Grimaudo, M.A.; Concheiro, A.; Alvarez-Lorenzo, C. Crosslinked hyaluronan electrospun nanofibers for ferulic acid ocular delivery. Pharmaceutics 2020, 12, 274. [CrossRef]

100. Varela-Garcia, A.; Concheiro, A.; Alvarez-Lorenzo, C. Cytosine-functionalized bioinspired hydrogels for ocular delivery of antioxidant transferulic acid. Biomater. Sci. 2020, 8, 1171-1180. [CrossRef]

101. Romeo, A.; Muscumeci, T.; Carbone, C.; Bonaccorso, A.; Corvo, S.; Lupo, G.; Anfuso, C.D.; Puglisi, G.; Pignatello, R. Ferulic acid-loaded polymeric nanoparticles for potential ocular delivery. Pharmaceutics 2021, 13, 687. [CrossRef] [PubMed]

102. Liu, C.S.; Chen, L.; Hu, Y.N.; Dai, J.L.; Ma, B.; Tang, Q.F.; Tan, X.M. Self-microemulsifying drug delivery system for improved oral delivery and hypnotic efficacy of ferulic acid. Int. J. Nanomed. 2020, 15, 2059-2070. [CrossRef] [PubMed]

103. Zyaitdinov, D.R.; Ewteew, A.V.; Bannikova, A.V. Immobilization of oat bran polyphenols in complex coacervates of whey protein and malthodextrin. Food Proc. Techniq. Technol. 2020, 50, 460-469. [CrossRef]

104. Heep, G.; Almeida, A.; Marcano, R.; Vieira, D.; Mainardes, R.M.; Khalil, N.M.; Sarmento, B. Zein-casein-lysine multicomposite nanoparticles are effective in modulate the intestinal permeability of ferulic acid. Int. J. Biol. Macromol. 2020, 138, 244-251. [CrossRef]

105. Awadalla, A.; Hussein, A.M.; El-Far, Y.M.; Barakat, N.; Hamam, E.T.; El-Sherbiny, M.; El-Shafey, M.; Shokeir, A.A. Effect of zinc oxide nanoparticles and ferulic acid on renal ischemia/reperfusion injury: Possible underlying mechanisms. Biomed. Pharmacol. 2021, 140, 111686. [CrossRef] [PubMed]

106. Zheng, Y.; You, X.; Chen, L.; Huang, J.; Wang, L.; Wu, J.; Guan, S. Biotherapeutic nanoparticles of poly(ferulic acid) delivering doxorubicin for cancer therapy. J. Biomed. Nanotechnol. 2019, 15, 1734-1743. [CrossRef] [PubMed]

107. Wang, Z.W.; Zhang, Z.H.; Qiao, Z.R.; Cai, W.D.; Yan, J.K. Construction and characterization of antioxidative ferulic acid-grafted carboxylic curdlan conjugates and their contributions on $\beta$-carotene storage stability. Food Chem. 2021, 349, 129166. [CrossRef] [PubMed]

108. Yu, Y.B.; Cai, W.D.; Wang, Z.W.; Yan, J.K. Emulsifying properties of a ferulic acid-grafted curdlan conjugate and its contribution to the chemical stability of $\beta$-carotene. Food Chem. 2021, 339, 128053. [CrossRef]

109. $\mathrm{Wu}, \mathrm{Y}$.; Zhang, G. Synbiotic encapsulation of probiotic Lactobacillus plantarum by alginate-arabinoxylan composite microspheres. LWT 2018, 93, 135-141. [CrossRef]

110. Puris, E.; Gynther, M.; Huttunen, J.; Auriola, S.; Huttunen, K.M. L-type amino acid transporter 1 utilizing prodrugs of ferulic acid revealed structural features supporting the design of prodrugs for brain delivery. Eur. J. Pharm. Sci. 2019, 129, 99-109. [CrossRef]

111. Trombino, S.; Ferrarelli, T.; Cassano, R. A New pro-prodrug aminoacid-based for trans-ferulic acid and silybin intestinal release. J. Funct. Biomater. 2014, 5, 99-110. [CrossRef] [PubMed]

112. Miyamato, S.; Epifano, F.; Curini, M.; Genovese, S.; Kim, M.; Ishigamori-Suzuki, R.; Yasui, Y.; Shigeyuki, S. A novel prodrug of 4'-gelanyloxy-ferulic acid suppresses colitis-related colon carcinogenesis in mice. Nutr. Cancer 2008, 60, 675-684. [CrossRef]

113. Tan, M.X.; Wang, Z.F.; Qin, Q.P.; Zou, B.Q.; Liang, H. Complexes of oxoplatin with rhein and ferulic acid ligands as platinum(IV) prodrugs with high anti-tumor activity. Dalton Trans. 2020, 49, 1613-1619. [CrossRef] [PubMed]

114. Kaki, S.S.; Kunduru, K.R.; Kanjilal, S.; Pradad, R.B.N. Synthesis and characterization of a novel phenolic lipid for use as potential lipophilic antioxidant and as a prodrug of butyric acid. J. Oleo Sci. 2015, 64, 845-852. [CrossRef] [PubMed] 